LETTER TO THE EDITOR

\title{
Current evidence on confocal laser endomicroscopy for noninvasive head and neck cancer imaging
}

\author{
Evidenze scientifiche attuali sulla endomicroscopia confocale laser nell'imaging \\ del tumore non invasivo del distretto testa e collo
}

\author{
Xi Yang ${ }^{1,2}$, Wei Liu² \\ ${ }^{1}$ Department of Oral and Maxillofacial-Head and Neck Oncology, Fengcheng Hospital of Fengxian District, Shanghai, China; \\ 2 Department of Oral and Maxillofacial-Head and Neck Oncology, Shanghai Ninth People's Hospital, College of Stomatology, \\ National Clinical Research Center for Oral Diseases, Shanghai Key Laboratory of Stomatology \& Shanghai Research Institute of \\ Stomatology, Shanghai Jiao Tong University School of Medicine, Shanghai, China
}

KEY WORDS: confocal laser endomicroscopy, head and neck squamous cell carcinoma, oral potentially malignant disorders, dysplasia, fluorescent molecular imaging

PAROLE CHIAVE: endomicroscopia laser confocale, carcinoma spinocellulare testa e collo, lesioni orali potenzialmente maligne, displasia, imaging molecolare a fluorescenza

\section{Dear Editor,}

We read with interest the article entitled "Probe-based confocal laser endomicroscopy in detecting malignant lesions of vocal folds" recently published in Acta Otorhinolaryngologica Italica by Goncalves et al. ${ }^{1}$. The authors determined the diagnostic value and inter-rater reliability of confocal laser endomicroscopy (CLE) by comparing 58 video sequences of 3 patients with squamous cell carcinomas (SCC) and 4 patients with benign alterations of the vocal folds ${ }^{1}$. CLE imaging features of SCC compared with the benign alterations were well characterised ${ }^{1}$, but the current evidence on CLE imaging in noninvasive detection of HNSCC is making progress and needs to be significantly expanded upon (Tab. I). This Letter aims to provide the reader with an up-to-date review of the literature on CLE in the setting of HNSCC. We classify the research topics of current investigations into CLE head and neck imaging, and briefly discuss current practices and challenges that implicate future directions.

In studies before 2014, the main objective of preliminary studies was to investigate the CLE imaging characteristics of head and neck cancer tissue compared to normal mucosa and surgical margins (reviewed in Abbaci et al. ${ }^{2}$ ). Earlier studies have shown that by using CLE, micro-anatomical structures of normal mucosa/margins and cancerous lesions can be well identified, allowing for differentiation of malignant and benign mucosal. However, these results should be interpreted prudently for several reasons: very small sample size, different measurement devices used, lack of diagnostic criteria based on micro-imaging of CLE. In addition, field of view and depth penetration of this technology have not yet been well addressed ${ }^{2}$.

Starting in 2014, the main objective of prior studies was to evaluate whether CLE is useful in diagnosing HNSCC ${ }^{3-8}$. According to preliminary data ${ }^{1,3,6-8}$, the sensitivity and specificity of diagnosing SCC was reported to
Received: April 18, 2020

Accepted: April 28, 2020

Correspondence

Wei Liu

Department of Oral and Maxillofacial-Head and Neck Oncology, Shanghai Ninth People's Hospital, Shanghai 200011, China

E-mail: liuweb@hotmail.com

\section{Funding}

This work was supported by Fengxian District Clinical Diagnosis \& Treatment Center of Oral and Maxillofacial-Head and Neck Oncology (fxlczlzx-a-201705) and Shanghai Municipal Health Committee (202040327).

\section{Conflict of interest}

The Authors declare no conflict of interest.

\begin{abstract}
How to cite this article: Yang X, Liu W. Current evidence on confocal laser endomicroscopy for noninvasive head and neck cancer imaging. Acta Otorhinolaryngol Ital 2020;40:396-398. https:// doi.org/10.14639/0392-100X-N0801
\end{abstract}

() Società Italiana di Otorinolaringoiatria e Chirurgia Cervico-Facciale

\section{(c) (1) $(9)$}

This is an open access article distributed in accordance with the CC-BY-NC-ND (Creative Commons Attribution-NonCommercial-NoDerivatives 4.0 International) license. The article can be used by giving appropriate credit and mentioning the license, but only for non-commercial purposes and only in the original version. For further information: https:// creativecommons.org/licenses/by-nc-nd/4.0/deed.en 
be $85.0-95.3 \%$ and $72.0-100 \%$, respectively. Additionally, the interobserver accuracy and reliability of CLE for discrimination of head and neck lesions from normal mucosa has also been investigated ${ }^{4-6}$. Intriguingly, the feasibility of automated analysis and classification of cancerous tissue in CLE head and neck imaging using deep learning has been demonstrated ${ }^{7,8}$. Although the results are promising, they are limited to mainly small descriptive studies. The standardised diagnostic protocols as well as clinically relevant classification systems for head and neck diseases have not yet been described. Moreover, the integration between pathologist and clinician/surgeon in the review process of CLE imaging has not been elucidated.

One of the greatest advantages of CLE with fluorescence is its potential for multiplex analyses in which morphological information can be combined with molecular and/or functional markers. Alterations in molecular and/or functional properties of a cancerous tissue can be translated into significant and optically measurable changes in fluorescent signals. In vivo molecular imaging of gastrointestinal cancer using CLE by targeting EGFR and VEGF has been demonstrated; this concept was recently applied to CLE head and neck cancer imaging with EpCAM and EGFR antibodies conjugated to fluorescent labels ${ }^{9,10}$. When combined with the molecular imaging capabilities of CLE at the cellular level, these new fluorescent targets can contribute to the currently pursued topic of personalised medicine in the field of head and neck cancer, by making it possible to predict the cells' response to the molecular imaging guided diagnosis and therapy.

In summary, the noninvasive point-of-care CLE for head and neck imaging at the cellular level, as a new emerging science, is of great promise for research, especially in molecular targeted chairside diagnosis and intraoperative normal margins. Multi-institutional studies on the three aforementioned research classifications are warranted to overcome the drawbacks and consolidate the value of CLE. The dynamic observation of early malignant changes at the cellular level is a crucial element in the understanding of patient-specific information and today, noninvasive CLE is probably the most versatile technology to face this challenge. Nevertheless, substantial researches are still needed in order to promote fluorescence molecular imaging techniques to the status of routine use in clinical practice for HNSCC.

Table I. Summary of the English-language literature of confocal laser endomicroscopy for diagnostic assessment of head and neck squamous cell carcinoma (SCC).

\begin{tabular}{|c|c|c|c|c|c|c|c|c|}
\hline $\begin{array}{l}\text { Year of } \\
\text { publication }\end{array}$ & $\begin{array}{l}\text { First } \\
\text { author }\end{array}$ & Country & Manufacturer & $\begin{array}{l}\text { No. of subjects } \\
\text { and location }\end{array}$ & Subject setting & Aim of study & $\begin{array}{l}\text { Sensitivity } \\
\%\end{array}$ & $\begin{array}{l}\text { Specificity } \\
\%\end{array}$ \\
\hline 2019 & $\begin{array}{l}\text { Goncalves } \\
\text { et al. }{ }^{1}\end{array}$ & Germany & CellVizio, France & Vocal folds & $\begin{array}{c}4 \text { benign vs. } 3 \\
\text { SCC }\end{array}$ & $\begin{array}{l}\text { Diagnostic assessment } \\
\text { and interobserver } \\
\text { agreement }\end{array}$ & $91.4-96.6$ & 100 \\
\hline 2014 & $\begin{array}{l}\text { Nathan et } \\
\text { al. }^{3}\end{array}$ & USA & CellVizio, France & Oral & $\begin{array}{c}12 \text { leukoplakia } \\
\text { vs. } 9 \text { SCC }\end{array}$ & $\begin{array}{c}\text { Diagnostic } \\
\text { assessment }^{\mathrm{a}}\end{array}$ & 85.7 & 100 \\
\hline 2016 & $\begin{array}{l}\text { Moore et } \\
\text { al. }{ }^{4}\end{array}$ & USA & CellVizio, France & Oral & $\begin{array}{l}6 \text { non-dysplasia } \\
\text { vs. } 7 \text { dysplasia } \\
\text { vs. } 11 \text { SCC }\end{array}$ & $\begin{array}{l}\text { Interobserver } \\
\text { agreement }\end{array}$ & NA & NA \\
\hline 2016 & $\begin{array}{l}\text { Linxweiler } \\
\text { et al. }{ }^{5}\end{array}$ & Germany & CellVizio, France & $\mathrm{HN}$ & $\begin{array}{l}50 \text { normal vs. } \\
135 \text { SCC }\end{array}$ & $\begin{array}{l}\text { Interobserver } \\
\text { agreement }^{\mathrm{b}}\end{array}$ & NA & NA \\
\hline 2016 & $\begin{array}{l}\text { Oetter et } \\
\text { al. }^{6}\end{array}$ & Germany & CellVizio, France & Oral & $\begin{array}{l}45 \text { normal } \\
50 \text { SCC }\end{array}$ & $\begin{array}{c}\text { Diagnostic assessment } \\
\text { and interobserver } \\
\text { agreement }\end{array}$ & 95.3 & 88.9 \\
\hline 2016 & $\begin{array}{l}\text { Dittberner } \\
\text { et al. }{ }^{7}\end{array}$ & Germany & CellVizio, France & $\begin{array}{l}\text { Oral, oropharynx, } \\
\text { others }\end{array}$ & $\begin{array}{l}\text { Self control of } 12 \\
\text { normal margins } \\
\text { and SCC }\end{array}$ & $\begin{array}{c}\text { Automated Diagnostic } \\
\text { assessment }\end{array}$ & 85.0 & 72.0 \\
\hline 2017 & $\begin{array}{l}\text { Aubreville } \\
\text { et al. }{ }^{8}\end{array}$ & Germany & CellVizio, France & oral & $\begin{array}{l}\text { Self control of } 12 \\
\text { normal margins } \\
\text { and SCC }\end{array}$ & $\begin{array}{c}\text { Automated Diagnostic } \\
\text { assessment }\end{array}$ & 86.6 & 90.0 \\
\hline 2017 & $\begin{array}{l}\text { Englhard et } \\
\text { al. }^{9}\end{array}$ & Germany & CellVizio, France & $\mathrm{HN}$ & $\begin{array}{l}5 \text { normal vs. } 11 \\
\text { SCC }\end{array}$ & $\begin{array}{l}\text { EGFR/EpCAM-targeted } \\
\text { micro-imaging }\end{array}$ & NA & NA \\
\hline 2019 & $\begin{array}{l}\text { Watermann } \\
\text { et al. }{ }^{10}\end{array}$ & Germany & $\begin{array}{l}\text { Optiscan, } \\
\text { Australia }\end{array}$ & NA & $\begin{array}{l}\text { Gingiva normal } \\
\text { vs. Oropharynx } \\
\text { SCC } \\
\end{array}$ & $\begin{array}{l}\text { EGFR nanoparticles- } \\
\text { targeted micro- } \\
\text { imaging }\end{array}$ & NA & NA \\
\hline
\end{tabular}




\section{References}

1 Goncalves M, Aubreville M, Mueller SK, et al. Probe-based confocal laser endomicroscopy in detecting malignant lesions of vocal folds. Acta Otorhinolaryngol Ital 2019;39:389-95. https://doi. org/10.14639/0392-100X-2121.

2 Abbaci M, Breuskin I, Casiraghi O, et al. Confocal laser endomicroscopy for non-invasive head and neck cancer imaging: a comprehensive review. Oral Oncol 2014;50:711-6. https://doi.org/10.1016/j. oraloncology.2014.05.002.

3 Nathan CA, Kaskas NM, Ma X, et al. Confocal Laser Endomicroscopy in the detection of head and neck precancerous lesions. Otolaryngol Head Neck Surg 2014;151:73-80. https://doi. org/10.1177/0194599814528660.

4 Moore C, Mehta V, Ma X, et al. Interobserver agreement of confocal laser endomicroscopy for detection of head and neck neoplasia. Laryngoscope 2016;126:632-7. https://doi.org/10.1002/lary.25646

5 Linxweiler M, Kadah BA, Bozzato A, et al. Noninvasive histological imaging of head and neck squamous cell carcinomas using confocal laser endomicroscopy. Eur Arch Otorhinolaryngol 2016;273:4473-83. https://doi.org/10.1007/s00405-016-4145-8
6 Oetter N, Knipfer C, Rohde M, et al. Development and validation of a classification and scoring system for the diagnosis of oral squamous cell carcinomas through confocal laser endomicroscopy. J Transl Med 2016;14:159. https://doi.org/10.1186/s12967-016-0919-4.

7 Dittberner A, Rodner E, Ortmann W, et al. Automated analysis of confocal laser endomicroscopy images to detect head and neck cancer. Head Neck 2016;38(Suppl 1):E1419-26. https://doi.org/10.1002/ hed. 24253

8 Aubreville M, Knipfer C, Oetter N, et al. Automatic classification of cancerous tissue in laserendomicroscopy images of the oral cavity using deep learning. Sci Rep 2017;7:11979. https://doi.org/10.1038/ s41598-017-12320-8

9 Englhard AS, Palaras A, Volgger V, et al. Confocal laser endomicroscopy in head and neck malignancies using FITC-labelled EpCAMand EGF-R-antibodies in cell lines and tumor biopsies. J Biophotonics 2017;10:1365-76. https://doi.org/10.1002/jbio.201600238

10 Watermann A, Gieringer R, Bauer AM, et al. Fluorescein- and EGFRantibody conjugated silica nanoparticles for enhancement of real-time tumor border definition using confocal laser endomicroscopy in squamous cell carcinoma of the head and neck. Nanomaterials (Basel) 2019;9:1378. https://doi.org/10.3390/nano9101378 